\title{
Vascular plant assemblages of ephemeral wetland vegetation along the Mediterranean-temperate gradient in Chile
}

\section{Ensambles de plantas vasculares asociadas a humedales temporales a lo largo del gradiente mediterráneo-templado en Chile}

\author{
Miguel Alvarez ${ }^{1 *} \&$ Ulrich Deil ${ }^{2}$ \\ ${ }^{1}$ Vegetation Ecology, INRES, University of Bonn, Nußallee 9, 53115 Bonn, Germany. \\ Department of Geobotany, Faculty of Biology, University of Freiburg, Schänzlestraße 1, 79104 Freiburg, Germany. \\ *malvarez@uni-bonn.de
}

\begin{abstract}
Plant species composition and geographical distribution of vernal pools in Mediterranean Chile are poorly studied. In order to overcome this gap we collected 73 floristic samples in the Mediterranean-temperate gradient from Chile (31$\left.44^{\circ} \mathrm{S}\right)$. Additionally, we carried out an exhaustive collection of published phytosociological relevés made in this area including some relevés from the East side of the Andes in Argentina. The resulting dataset contains 228 observations of 269 species. Hierarchical clustering was applied in order to get co-occurrence assemblages. These sets were compared with diagnostic groups defined a priori, life forms and their status in South America (introduced vs native species). In order to detect geographic and climatic distribution patterns of the assemblages, we extracted climatic summary variables from the WorldClim database and performed a principal component analysis (PCA). We detected seven species assemblages with a significant correspondence to diagnostic groups defined a priori $(\mathrm{P}<0.01)$, though their association is relatively low (Cramér's $\mathrm{V}=0.49$ ). Native species dominate over adventive ones in each assemblage suggesting low risk of outcompetition by introduced species adapted to these habitats. The annual life form is over represented in most of the cooccurrence groups. Despite the huge temperature and precipitation gradient in the studied transect, plant assemblages are occurring almost along the whole range, supporting the hypothesis of azonality (low dependence on macro-climate). Assemblages defined in this work can be potentially used for further supervised classification strategies in order to define plant community types within vernal pool vegetation.
\end{abstract}

KEYwords: Ecological groups, phytosociology, syntaxonomic classification, vernal pools, vegetation database.

\begin{abstract}
RESUMEN
Actualmente se conoce muy poco sobre la composición florística y la distribución geográfica de humedales temporales en Chile mediterráneo. Con el fin de llenar este vacío, se realizaron 73 inventarios florísticos en el gradiente mediterráneotemplado de Chile ( $\left.31-44^{\circ} \mathrm{S}\right)$. Además, se llevó a cabo una búsqueda bibliográfica exhaustiva de inventarios fitosociológicos en publicaciones científicas, incluyendo algunos inventarios de la parte argentina de la Cordillera de los Andes. Se obtuvo una matriz con 228 observaciones y 269 especies. Se aplicó una clasificación jerárquica para generar ensambles de coocurrencia. Dichos ensambles fueron comparados con grupos de especies diagnósticas definidas a priori, con formas de vida y tipos de origen (especies introducidas en Sudamérica vs especies nativas). Para determinar patrones de distribución geográfica y climática, se extrajeron variables del modelo WorldClim y se aplicaron a un análisis de componentes principales (PCA). Según la clasificación jerárquica se determinaron siete ensambles de especies con una alta correspondencia a los grupos definidos a priori $(\mathrm{P}<0,01)$, sin embargo con un nivel relativamente bajo de asociación (índice $\mathrm{V}$ de $\mathrm{Cramér}=$ 0,49). En la vegetación estudiada dominan las especies nativas sobre las introducidas, lo que sugiere un bajo riesgo de extinción por competencia con especies introducidas adaptadas a este tipo de ambientes. La forma de vida anual está sobrerrepresentada en la mayoría de los ensambles. Pese al enorme gradiente de temperatura y precipitación incluido en el rango de las muestras, los ensambles se distribuyen a lo largo de todo este gradiente, apoyando la hipótesis de azonalidad (indiferencia al macro-clima). Los ensambles definidos en este trabajo pueden ser potencialmente utilizados para posteriores clasificaciones supervisadas con el fin de definir tipos de comunidades vegetales en lagunas temporales.
\end{abstract}

Palabras clave: Grupos ecológicos, fitosociología, clasificación sintaxonómica, lagunas temporales, bases de datos vegetacionales. 


\section{INTRODUCTION}

Ephemeral wetlands are habitats with a restricted time window for plant growth due to the alternation of flooding periods with dry ones. In a global revision, Deil (2005) classified these habitats in three main types: seasonal pools, shorelines of lakes and rivers with fluctuating water level and ephemeral flushes on inselbergs. Seasonal pools and in particular vernal pools occur in the Mediterranean biomes of the world, namely in Australia, South of Africa (Capensis region), the Circum-Mediterranean area (southern Europe and northern Africa), California (eastern USA) and central Chile (Deil 2005). According to Keeley \& Zedler (1998), vernal pools are defined as pools filled by winter rains and desiccating in summer. Growth and generative reproduction of the plant species are concentrated on the aquatic phase in spring and the amphibic phase in early summer. The occurrence of these habitats is determined by strong seasonality of temperature and rainfall. Low water permeability of the substrate and an undulating relief with small depressions are further preconditions (Deil 2005). Since vernal pools are not affected by long-distance drainage (Keeley \& Zedler 1998), soil chemistry and water properties are locally determined.

Vernal pools are colonized by a highly specialized flora, adapted to a strong seasonal dynamic on water availability. Such specialists are frequently accompanied by opportunistic species from the surrounding habitats. The spatial isolation of the vernal pools favours allopatric speciation, resulting in endemic taxa and geographical vicariants, especially in taxa with restricted dispersal capacity. On the other hand, ephemeral wetland species with long-distance dispersal capacity can reach a cosmopolitan distribution (Deil 2005).

In Chile vernal pools are poorly studied. Most of the research is restricted to floristic surveys done at the local scale. A first floristic analysis and vegetation study over a broader geographical area and along the north-south precipitation gradient from the semi-arid via the subhumid Mediterranean to the temperate bioclimate in Chile was realized by Bliss et al. (1998). These authors collected data along transects, crossing the whole vernal pool and including habitats of very different inundation period and becoming amphibic in different seasons. Hence such data are not suitable to look for phytocoenoses related to specific environmental conditions.

Vernal pools offer a habitat to native annuals, many of them endemic in Chile (Arroyo et al. 1990). Additionally, many of these annual species belong to mono-specific genera, such as the Asteraceae Blennosperma, Centipeda, Lasthenia, Micropsis and Microseris (Moreira-Muñoz \& Muñoz-Schick 2007, Moreira-Muñoz 2011). The distribution and ecology of vernal pool plant species is poorly known (Alvarez et al. 2008, 2012b). An analysis, which species are restricted to the vernal pool habitat and how they are distributed can be a first step to evaluate their vulnerability and the extinction risk and to assess their importance for conservation of plant diversity at the regional, national and even continental scale. On the other hand, Chilean vernal pools often occur in man-made pastures and in other disturbed areas such as trampling paths (Deil et al. 2007), livestock watering ponds (San Martín et al. 1998) and gravel quarries (Ramírez et al. 1996), resulting in a significant participation of European alien plants in Chilean vernal pools. This phenomenon is also mentioned for vernal pools in California, were the high frequency of Briza minor, Leontodon taraxacoides, Lythrum hyssopifolia, Picris echioides, Medicago polymorpha, Sonchus asper, Trifolium dubium and Vulpia bromoides is recorded (Barbour et al. 2003, Gerhardt \& Collinge 2003). All these species of Palaearctic origin are also occurring in Chilean vernal pools. The dominance of non-native species may reflect the degree of disturbance in those habitats.

Vernal pools in Chile are distributed over a long gradient of temperature and rainfall, for instance annual rainfall ranges from less than 100 to more than $1,000 \mathrm{~mm}$ (Bliss et al. 1998). This huge gradient is reflected in the zonal vegetation dominated by semi-desert coastal scrubs in the north respectively temperate evergreen forests in the south (Luebert \& Pliscoff 2006). Although this gradient is crossing through four floristic regions defined by Bannister et al. (2012), we hypothesise that vernal pools specialists react more sensitively to local conditions along the inundation gradient by forming different plant assemblages in the pool bottom, the fringes and the surrounding upland areas (see examples from other Mediterranean areas in the world in Deil 2005), but are less affected by macro-climatic conditions, showing an azonal character.

The aims of this work are to classify Chilean vernal pool species into co-occurrence groups (assemblages) and to check the correlation between their distribution along the studied gradient ( $31^{\circ}$ to $43^{\circ}$ south latitude) and macroclimatic parameters (temperature and rainfall). Additionally we aim to compare the resulting assemblages with current syntaxonomical lists of diagnostic species, life forms and species status (i.e. native or introduced species).

\section{METHODS}

DATA COLleCtion

In early spring of 2009 (September-October) we searched for vernal pools in Mediterranean Chile from $31^{\circ}$ to $38^{\circ} \mathrm{S}$ and at localities recorded by Bliss et al. (1998). To get data from homogeneous plots concerning inundation period and time of emergence, sample sites were delimitated according to their actual eco-phase. Following Pott \& Remy (2000), we separated in each of the pools the hydrophase, littoral, limose, and terrestrial eco-phases. Plot size was 1 or $2 \mathrm{~m}^{2}$ depending on the size of the whole stand and the slope angle towards the pool centre. In total 73 relevés were sampled in 
33 pools. The number of relevés per pool varies from 1 to 4 .

Complementing the relevés sampled in 2009, we included in the dataset published records focussing on the syntaxonomic classes Limoselletea australis, Littorelletea australis and Nanojuncetea australis (community groups G, H and I in Deil et al. 2011, respectively). These records are not only restricted to Chile but some are located in the Western Argentinean Patagonia area (Eskuche 2005). Since previous studies (Alvarez 2008, Deil et al. 2007, Ramírez et al. 1994) and field observations showed close floristic relationships between seasonal wetland vegetation in the late terrestrial eco-phase and surrounding annual dry grassland communities we also added to this analysis the communities studied by Deil et al. (2007), which were included into the Helianthemetea guttati, a class of annual dry grassland in Mediterranean climate regions. The final dataset included records from 228 plots. Though most of the ephemeral wetlands studied here may correspond to vernal pools, typical of the Mediterranean belt and the temperate areas with dry summer, some of the stands can be also representing autumnal pools (sensu Deil 2005) occurring at the shoreline of lakes with fluvio-nival regimes, such as the case of the relevés collected in the Argentinean Andes by Eskuche (2005).

Relevés analysed in this work (Table I) are stored in CLDataveg, a database formatted for Turboveg (Hennekens \& Schaminée 2001), focussing on Chilean herb vegetation (Alvarez et al. 2012a) and indexed with the code SACL-001 in the Global Index of Vegetation-Plot Databases (Dengler et al. 2011). The nomenclature of plant species follows Zuloaga et al. (2008).

TABLE I. Sources of relevés used for the determination of plant assemblages in seasonal wetlands of Chile and Argentina. Some of the plant community names are tentative. ID is the access number in the database CL-Dataveg.

TABLA I. Fuentes de inventarios usados para la determinación de ensambles de plantas asociadas a lagunas temporales de Chile y Argentina. Algunos de los nombres de comunidades vegetales son tentativos. ID es el número de acceso en la base de datos CL-Dataveg.

\begin{tabular}{|c|c|c|c|}
\hline \multirow[t]{2}{*}{ SOURCE } & \multirow[t]{2}{*}{ Plant COMMUNITY } & NUMBER OF & ID \\
\hline & & RELEVÉS & \\
\hline \multicolumn{4}{|l|}{ DATA SAMPLED IN CHILE } \\
\hline Original for this work & Several communities & 73 & $1-73$ \\
\hline \multirow[t]{2}{*}{ Alvarez (2008) } & Leontodo saxatilis-Piptochaetietum navarretietosum & 4 & $(98-105)$ \\
\hline & Leontodo saxatilis-Piptochaetietum micropsietosum & 4 & $(98-105)$ \\
\hline \multirow[t]{2}{*}{ Deil et al. (2007) } & Crassula closiana-Microseris pygmaea comm. & 11 & $74-84$ \\
\hline & Hypochaeris glabra-Leontodon taraxacoides comm. & 5 & $85-89$ \\
\hline \multirow[t]{5}{*}{ San Martín et al. (1998) } & Eleocharietum pachycarpae & 11 & $183-193$ \\
\hline & Eleocharietum macrostachyae & 7 & $194-200$ \\
\hline & Gnaphalio cymatoidis-Polygonetum hydropiperoidis & 7 & 201-207 \\
\hline & Eleocharis pachycarpa-Lythrum portula comm. & 5 & $215-219$ \\
\hline & Phyla nodiflora-comm. & 4 & $224-227$ \\
\hline Ramírez et al. (1996) & Polygono aviculare-Crassuletum paludosae & 2 & $106-107$ \\
\hline \multirow[t]{3}{*}{ Ramírez et al. (1994) } & Leontodo-Piptochaetietum navarretietosum & 20 & $108-127$ \\
\hline & Leontodo-Piptochaetietum micropsietosum & 20 & $128-147$ \\
\hline & Mentha pulegium-Juncus procerus-comm. & 4 & $148-151$ \\
\hline \multirow[t]{4}{*}{ Oberdorfer (1960) } & Gratiolo peruviani-Littorelletum australis & 2 & $90-91$ \\
\hline & Juncetum planifolii & 3 & $92-94$ \\
\hline & Anagallis alternifolia-Juncus planifolius comm. & 1 & 95 \\
\hline & Scirpo inundati-Limoselletum aquaticae & 2 & $96-97$ \\
\hline \multicolumn{4}{|c|}{ DATA SAMPLED IN ARGENTINA } \\
\hline \multirow[t]{6}{*}{ Eskuche (2005) } & Arenario serpentis-Azorelletum trifoliatae & 9 & $230-238$ \\
\hline & Carici deciduae-Senecionetum zostaerifolii & 10 & $239-248$ \\
\hline & Senecioni zostaerifolii-Littorelletum australis & 10 & $249-258$ \\
\hline & Crassulo peduncularis-Limoselletum lineatae & 4 & $259-262$ \\
\hline & Downingio pusillae-Isoëtetum chubutiana & 4 & $263-266$ \\
\hline & Hydrocotylo chamaemori-Juncetum arctici & 6 & $267-272$ \\
\hline
\end{tabular}


The subset used for this work is restricted to vascular plants (269 taxa in total; mosses, lichens and algae are excluded). We added the coordinates of sampling localities, which were either recorded in the field by using a GPS device (i.e. plots sampled in 2009) or read from digital maps according to the descriptions of study sites in the respective bibliographic sources. The relevés are distributed in a range over about $1,000 \mathrm{~km}$ in the North-South direction (Fig. 1), from the Mediterranean into the temperate bioclimate according to Amigo \& Ramírez (1998), and the ombrotypes semi-arid to hyper-humid according to Luebert \& Pliscoff (2006). This gradient includes sites with annual mean temperatures ranging from 6.3 to $17.2^{\circ} \mathrm{C}$ and annual rainfall ranging from 171 to $2,417 \mathrm{~mm}$.

Classification of SPECIES AND COMPARISON With GROUPS DEFINED A PRIORI, LIFE FORMS AND STATUS

In order to produce sociological groups of species (species of similar ecological requirements), we classified them into co-occurrence groups (inverse classification according to Wilson et al. 1990). Previous to analysis the input dataset was formatted in a vegetation matrix of species as rows and relevés as columns (transposed vegetation table). Rare species, occurring in less than 7 plots, were excluded from the input matrix. Such species could be recorded by chance or due to introgression from the local neighbouring vegetation and may interfere in the statistical analyses. Hence the 269 vascular plant species included in the original dataset were reduced to 114 species. In order to enhance the discrimination capacity of the classification, abundance was rescaled to 4 classes using 25\%-steps (Van der Maarel 1979). A distance matrix comparing species was calculated after logarithmic transformation of abundance, using the formula $x^{\prime}=\ln (1+x)$, and calculation of BrayCurtis index as 1 - index. The resulting dissimilarity matrix was submitted to hierarchical clustering using the algorithm Ward1 (Murtagh \& Legendre 2014). The clustering displayed as a dendrogram was visually assessed to define clusters' cut level according to the length of branches. The clusters were contrasted against a null hypothesis of "no class structure" using the Multiple Response Permutation Procedure (MRPP) according to Mielke et al. (1981) and Van Sickle \& Hughes (2000). This test was applied to the same dissimilarity matrix as for classification and running 1,000 permutations. In this analysis the index A (chance corrected within-group agreement) estimates the proportion of the distances explained by group identity and varies from 1 (all sample within groups are identical) to 0 (withingroup heterogeneity equals the expectation by chance). Both, hierarchical clustering and MRPP were carried out using the package vegan (http://CRAN.R-project.org/ package $=$ vegan) in the statistical computing language R (http://www.R-project.org). For a direct import of the Turboveg database to the $\mathrm{R}$ console we used the package vegdata (Jansen \& Dengler 2010). For the manipulation and display of the classification dendrogram we used the package ggdendro (http://CRAN.R-project.org/package=ggdendro).

An additional a priori classification of species was defined according to available syntaxonomic studies. In such studies, plant species with high fidelity values for a syntaxa (class, order, alliance or association) are defined as diagnostic. Thus a diagnostic species of a class is frequently occurring in this class and absent in other classes due to matching of ecological requirements of this species and the properties of habitats occupied by the class (Bruelheide 2000). Diagnostic species for the classes Nanojuncetea australis, Limoselletea australis and Littorelletea australis

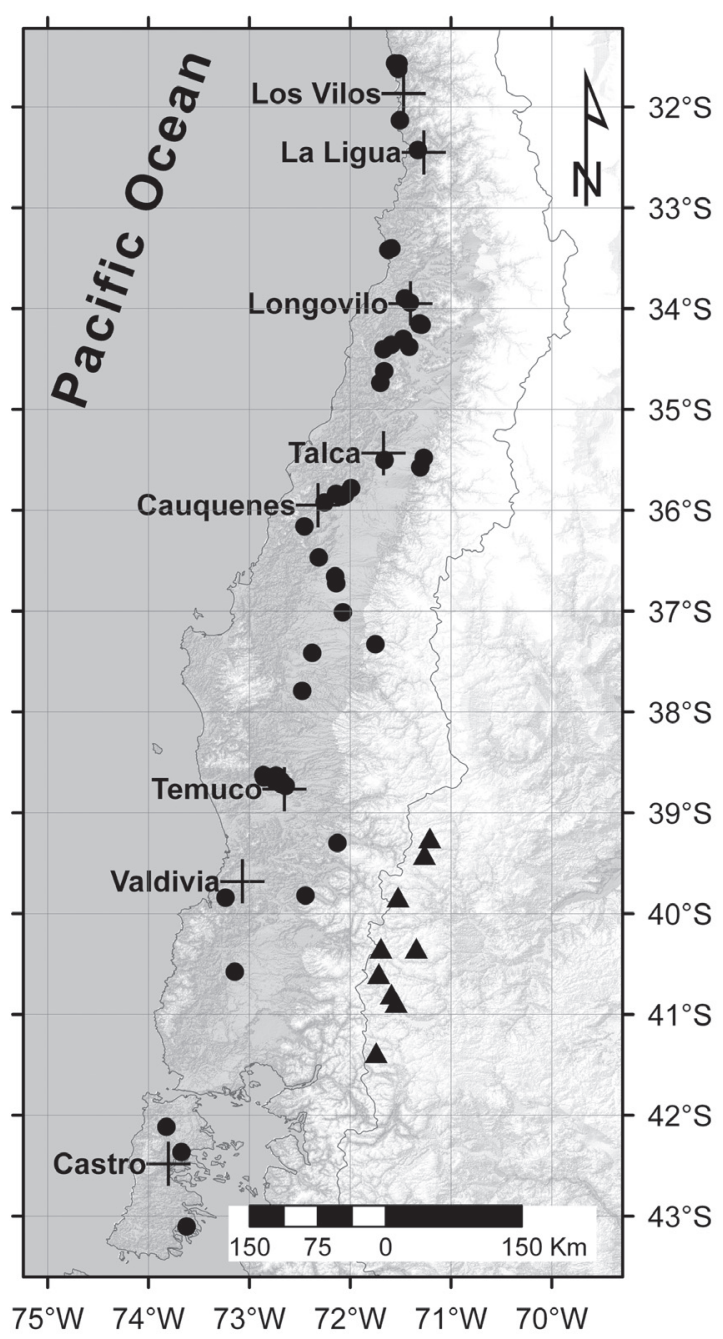

FIgURE 1. Geographical distribution of analyzed samples. Points: sample plots in Chile, triangles: sample plots in Argentina, crosses: localities of the reference weather stations.

FIgURA 1. Distribución geográfica de las muestras analizadas. Puntos: muestras de Chile, triángulos: muestras de Argentina, cruces: estaciones meteorológicas usadas como referencia. 
were defined according Deil et al. (2011), while species for dry annual turfs (Helianthemetea guttati) were extracted from Deil et al. (2007) (Table II). Additional information about life forms (Raunkiaer's classes) and status of the species (native or introduced) in Chile was collected from reference checklists (i.e. Arroyo et al. 1990 and Zuloaga et al. 2008). This information is displayed in Appendix A.

The correspondence of assemblages to groups defined a priori, life forms and status of species was estimated by calculating the Cramér's V coefficient and checked with Pearson's chi squared test (Backhaus et al. 2006). For that purpose, the function assocstats of the R-package ved (version 1.2-12, http://CRAN.R-project.org/package=vcd) was applied.

DESCRIPTION OF CLIMATIC GRADIENTS

To describe the climatic gradient following the latitudinal distribution of sites we superimposed an ESRI-shapefile over climatic raster-dataset obtained from the WorldClim database (Hijmans et al. 2005). The climatic information was transferred to the shapefile by using the Hawth's analysis tools plug-in (http://www.spatialecology.com) in the software ArcGIS (http://www.esri.com). We also compared climatic parameters for some stations published in Luebert \& Pliscoff (2006) and shown in Figure 1 against the simulated data stored in the WorldClim database.

In order to reduce the redundancy by highly correlated climatic variables, a principal component analysis (PCA) was carried out using the R-function prcomp. Coordinates and climatic information were imported from the ESRIshapefile to R using the package maptools (http://CRAN.Rproject.org $/$ package $=$ maptools). Herewith we eliminated duplicates in the dataset (plots sampled in the same locality). Previous to analysis we re-scaled the values of each climatic variable to a distribution with mean value 0 and standard deviation 1 by using the R-function scale. To determine correlations between variables we used the PCA loadings, where high and low values indicate positive respectively negative correlation of a variable with a PCA axis. To analyse the correspondence between presence of species and PCA dimensions summarizing correlated climatic variables, we exported the PCA scores to the sampling localities into the dataset and draw boxplots showing the dispersal of assemblages in the PCA scores.

TABLE II. Diagnostic groups of plant species defined a priori according to Deil et al. (2011) and Deil et al. (2007).

TABLA II. Grupos de plantas diagnósticas definidas a priori según Deil et al. (2011) y Deil et al. (2007).

NAA: NANoJuncetea Australis (cf. Isoëtalia, Isoëto-Nanojuncetea)

Blennosperma chilense, Bromidium trisetoides, Calotheca brizoides, Cardamine valdiviana, Centipeda elatinoides, Centunculus minimus, Cicendia quadrangularis, Cyperus eragrostis, C. reflexus, Deschampsia danthonioides, Dichondra sericea, Dioscorea fastigiata, Eryngium humifusum, E. pseudojunceum, Gamochaeta spiciformis, Pseudognaphalium cymathoides, Gratiola peruviana, Hydrocotyle cryptocarpa, Juncus bufonius, J. capitatus, J. imbricatus, J. planifolius, J. procerus, Lasthenia kunthii, Leontodon taraxacoides, Lotus subpinnatus, Lythrum hyssopifolia, L. portula, Mentha pulegium, Micropsis nana, Nassella poeppigiana, Navarretia involucrata, Nierembergia repens, Nothoscordum gramineum, Oldenlandia salzmannii, Paspalum dasypleurum, Phyla canescens, Piptochaetium montevidense, Plagiobothrys pratensis, Polygonum hydropiperoides, Sisyrinchium graminifolium, Stenandrium dulce, Triptilion spinosum

LMO: LimoselLETEA AUSTRALIS (cf. Nanocyperetalia, Isoëto-Nanojuncetea)

Crassula peduncularis, Elatine triandra, Juncus ebracteatus, J. pallescens, J. uruguensis, Lilaeopsis macloviana, Limosella australis, Soliva triniifolia

LTT: LitTORELLETEA AUSTRALIS (cf. Littorelletalia uniflorae, Isoëto-Littorelletea)

Anagallis alternifolia, Azorella trifoliolata, Carex decidua, C. sangei, Downingia pusilla, Eleocharis maculosa, E. pachycarpa, Equisetum bogotense, Hydrocotyle chamaemorus, Isoëtes chubutiana, Isolepis inundata, Juncus balticus ssp. andicola, J. stipulatus, Leptophyllochloa micrathera, Lindernia procumbens, Littorella australis, Myosurus apetalus, Plagiobothrys corymbosus, Ranunculus hydrophilus, $R$. trullifolius, Senecio zosterifolius

ANN: COMMUNITIES DOMINATED By DWARF ANNUALs (cf. Chaetanthero-Vulpion, Helianthemetea guttati)

Aira caryophyllea, Briza minor, Cerastium glomeratum, Chaetanthera ciliata, Crassula closiana, Hypochaeris glabra, Logfia gallica, Medicago polymorpha, Microseris pygmaea, Oxalis micrantha, Oziroë biflora, Plagiobothrys procumbens, Rumex acetosella, Soliva sessilis, Trifolium amabile, T. glomeratum, T. suffocatum, Vulpia bromoides 


\section{RESULTS}

\section{Species assemblages}

According to hierarchical clustering we defined 7 cooccurrence groups and arranged them from north to south according to their median latitudinal distribution. The classification dendrogram is presented in Fig. 2, indicating species groups defined a priori for a preliminary overview of correlations between those groups. According to the MRPP, the null hypothesis of no-cluster structure was rejected (P-value $<0.01)$. In the analysis the value of the chance corrected within-group agreement is relatively low $(\mathrm{A}=0.23)$. The size of the groups ranges from 9 (assemblage 6) to 22 species (assemblage 7).

Classification a PRIORI, LIFE FORMS AND STATUS Versus ASSEMBLAGES

From the 114 species used for the classification, $40 \%$ were considered as companion species, while $32 \%$ of them were considered as diagnostic species for the class Nanojuncetea australis. Most of the dwarf wetland annuals were clustered in assemblage 1, while assemblage 6 is dominated by Nanojuncetea australis and assemblage 7 by Littorelletea australis species. Limoselletea australis species are assigned to the assemblages 5 and 7 (Table III, see also Fig. 2).
$53 \%$ of the species are therophytes (annuals), followed by hemicryptophytes (34\%). Therophytes dominate the assemblages 1, 2, 4 and 5, while hemicryptophytes are dominating the assemblages 3,6 and 7 . About $73 \%$ of the analysed species are native ones. They are also the majority in every assemblage.

According to the Pearson's chi-squared test, significant p-values $(\mathrm{P}<0.05)$ were observed in the comparisons of assemblages versus groups defined a priori and versus life forms (Table III). Therefore, the null-hypothesis of nondependency was rejected in those cases, while the status of species (native/non-native) is not related to assemblages ( $\mathrm{P}$ $=0.12$ ). Despite to these findings, the correspondence of assemblages with groups defined a priori and life forms is relatively weak considering values of the Cramér's V ( 0.49 for species groups and 0.42 for life forms), since the values of this index vary between 0 (no correlation) and 1 (perfect correlation).

\section{GEOGRAPHIC DISTRIBUTION AND MACRO-CLIMATIC GRADIENT}

The latitudinal distribution of species is in general very variable within co-occurrence groups (Fig. 3, bottom). Most of the groups occur along the whole gradient. Assemblages 1 to 5 have a latitudinal median between $34^{\circ} \mathrm{S}$ and $37^{\circ} \mathrm{S}$, while assemblages 6 to 7 have their medians between $38^{\circ} \mathrm{S}$ and $40^{\circ} \mathrm{S}$.

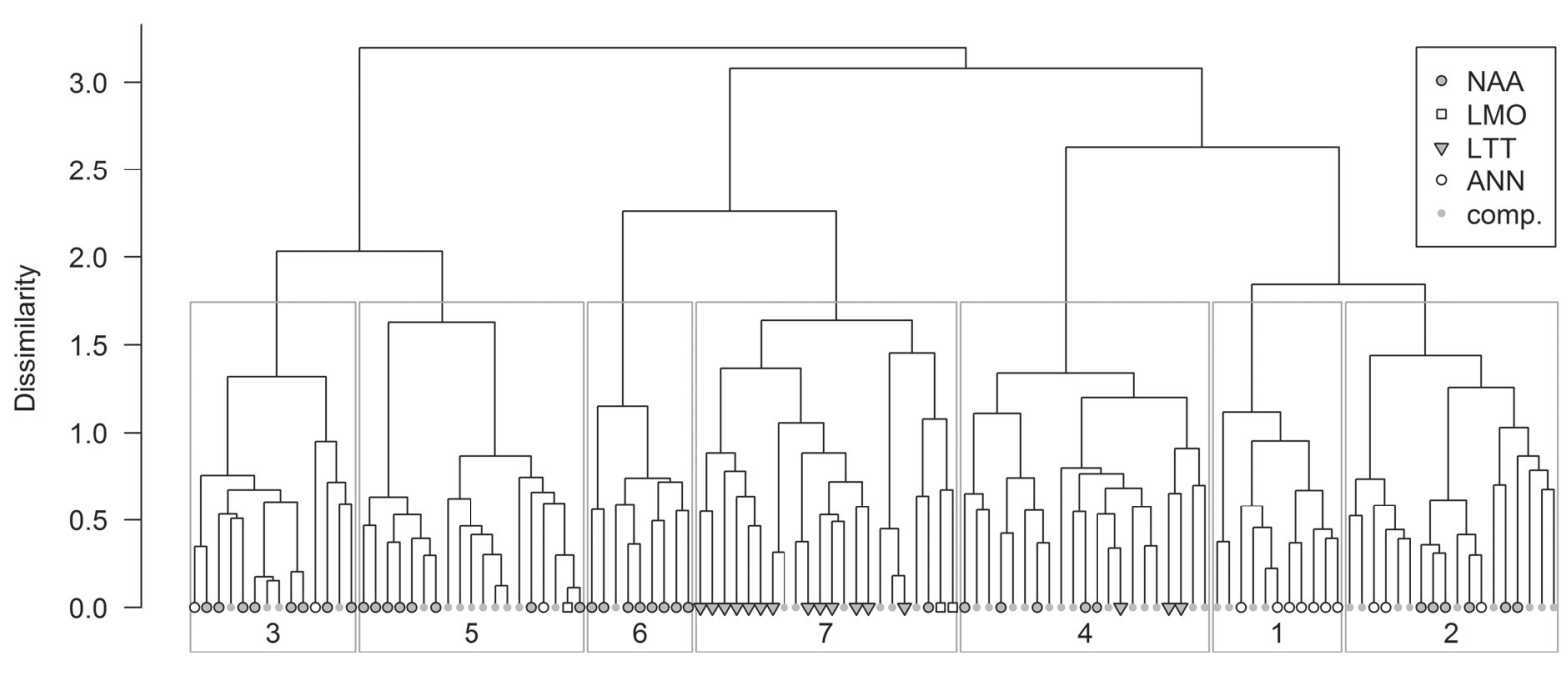

FIGURE 2. Classification dendrogram of species according to hierarchical clustering. Symbols of single species show groups defined a priori (see legend): Nanojuncetea australis (NAA), Limoselletea australis (LMO), Littorelletea australis (LTT), communities dominated by annual dwarf species (ANN) and companion species (comp.). Grey frames show the single assemblages with assigned numbers (identifiers) bellow.

FiguRa 2. Dendrograma de clasificación jerárquica de especies. Los símbolos para las especies muestran los grupos definidos a priori (ver leyenda): Nanojuncetea australis (NAA), Limoselletea australis (LMO), Littorelletea australis (LTT), comunidades dominadas por especies nano-terófitas (ANN) y especies acompañantes (comp.). Los rectángulos grises muestran los ensambles con los números asignados (identificadores) debajo. 
TABLE III. Cross classification table comparing species assemblages obtained by hierarchical clustering versus species groups defined a priori (A), life forms (B) and status of the species in South America (C). Groups defined a priori are coded as NAA (Nanojuncetea australis species group), LMO (Limoselletea australis species group), LTT (Littorelletea australis species group), ANN (dwarf annuals or Chaetanthero-Vulpion species group), and comp. (companion species). Life forms are coded as $\mathrm{T}$ (therophytes, i.e. annuals), Cr (cryptophytes, including bulb plants), $\mathrm{H}$ (hemicryptophytes), and Ch (chamaephytes). Species status is either native (nat.) or introduced (int.). Cramér's V coefficient (V) and the p-value of the Pearson's chi-squared test (P) are indicated for each factor.

TABLA III. Tabla de clasificación cruzada de la comparación de ensambles de especies obtenidos de la clasificación jerárquica con grupos definidos a priori (A), formas de vida (B) y origen de especies (C). Los grupos definidos a priori están codificados como NAA (especies de Nanojuncetea australis), LMO (especies de Limoselletea australis), LTT (especies de Littorelletea australis), ANN (nano-terófitas o especies del Chaetanthero-Vulpion), y comp. (especies acompañantes). Formas de vida son abreviadas como T (terófitas, i.e. plantas anuales), $\mathrm{Cr}$ (criptófitas, inclusive plantas bulbosas), $\mathrm{H}$ (hemicriptófitas), y Ch (caméfitas). El origen corresponde a plantas nativas (nat.) o introducidas (int.). Además se indica para cada factor el coeficiente V de Cramér's (V) y el valor de p para el test de chi cuadrado de Pearson (P).

\begin{tabular}{|c|c|c|c|c|c|c|c|c|c|c|c|}
\hline \multirow[b]{2}{*}{ FACTOR } & \multirow[b]{2}{*}{ Classes } & \multicolumn{7}{|c|}{ AssemBlaGES } & \multirow[b]{2}{*}{ SUM } & \multirow[b]{2}{*}{$\mathrm{V}$} & \multirow[b]{2}{*}{$\mathrm{P}$} \\
\hline & & 1 & 2 & 3 & 4 & 5 & 6 & 7 & & & \\
\hline \multirow[t]{5}{*}{ A: Groups a priori } & NAA & - & 6 & 8 & 5 & 8 & 8 & 1 & 36 & 0.49 & $<0.01$ \\
\hline & LMO & - & - & - & - & 1 & - & 2 & 3 & & \\
\hline & LTT & - & - & - & 3 & - & - & 13 & 16 & & \\
\hline & ANN & 7 & 3 & 2 & - & 1 & - & - & 13 & & \\
\hline & comp. & 4 & 9 & 4 & 13 & 9 & 1 & 6 & 46 & & \\
\hline \multirow[t]{4}{*}{ B: Life forms } & $\mathrm{T}$ & 9 & 17 & 4 & 14 & 10 & 1 & 5 & 60 & 0.42 & $<0.01$ \\
\hline & $\mathrm{Cr}$ & 2 & 1 & - & 5 & 2 & - & 4 & 14 & & \\
\hline & $\mathrm{H}$ & - & - & 10 & 2 & 6 & 8 & 13 & 39 & & \\
\hline & $\mathrm{Ch}$ & - & - & - & - & 1 & - & - & 1 & & \\
\hline \multirow[t]{2}{*}{ C: Status } & int. & 4 & 8 & 5 & 2 & 7 & 2 & 3 & 31 & 0.30 & 0.12 \\
\hline & nat. & 7 & 10 & 9 & 19 & 12 & 7 & 19 & 83 & & \\
\hline Total species & & 11 & 18 & 14 & 21 & 19 & 9 & 22 & 114 & & \\
\hline
\end{tabular}

The sampling localities show a clear geographic and climatic pattern from higher mean temperatures and lower rainfall in the North to cooler and wetter climate in the South. Mean annual temperature ranges from 17.2 to 6.3 ${ }^{\circ} \mathrm{C}$, while annual rainfall varies between 171 and 2,417 $\mathrm{mm}$. Climatic stations used as reference show a very similar trend in the latitudinal direction. Although Argentinean plots are located at higher altitudes at same latitudes of Chilean plots, they do not divert too much in the mentioned climatic patterns (Fig. 3).

According to the PCA loadings, 4 groups of climatic variables could be defined, highly correlated between each other (Table IV). The first group contains variables negatively correlated with PCA 1 , most of them related with mean temperature (bio_1) but also precipitation seasonality (bio_15). The second group is positively correlated with PCA 1 and contains variables related with annual precipitation (bio_12). A third group of variables with highly positive loadings in PCA 2 is related with temperature oscillation patterns like the annual range (bio_7) and the temperature seasonality (bio_4). The isothermality (bio_3) has low loadings in PCA 1 and PCA 2 but a high negative correlation with PCA 3. The three first PCA dimensions used to build these groups resume about $92 \%$ of the total variability of the data. The latitude, also included in this analysis, is mainly correlated with PCA 1, indicating the geographic trend in the ordination from low (North) to high scores (South). 


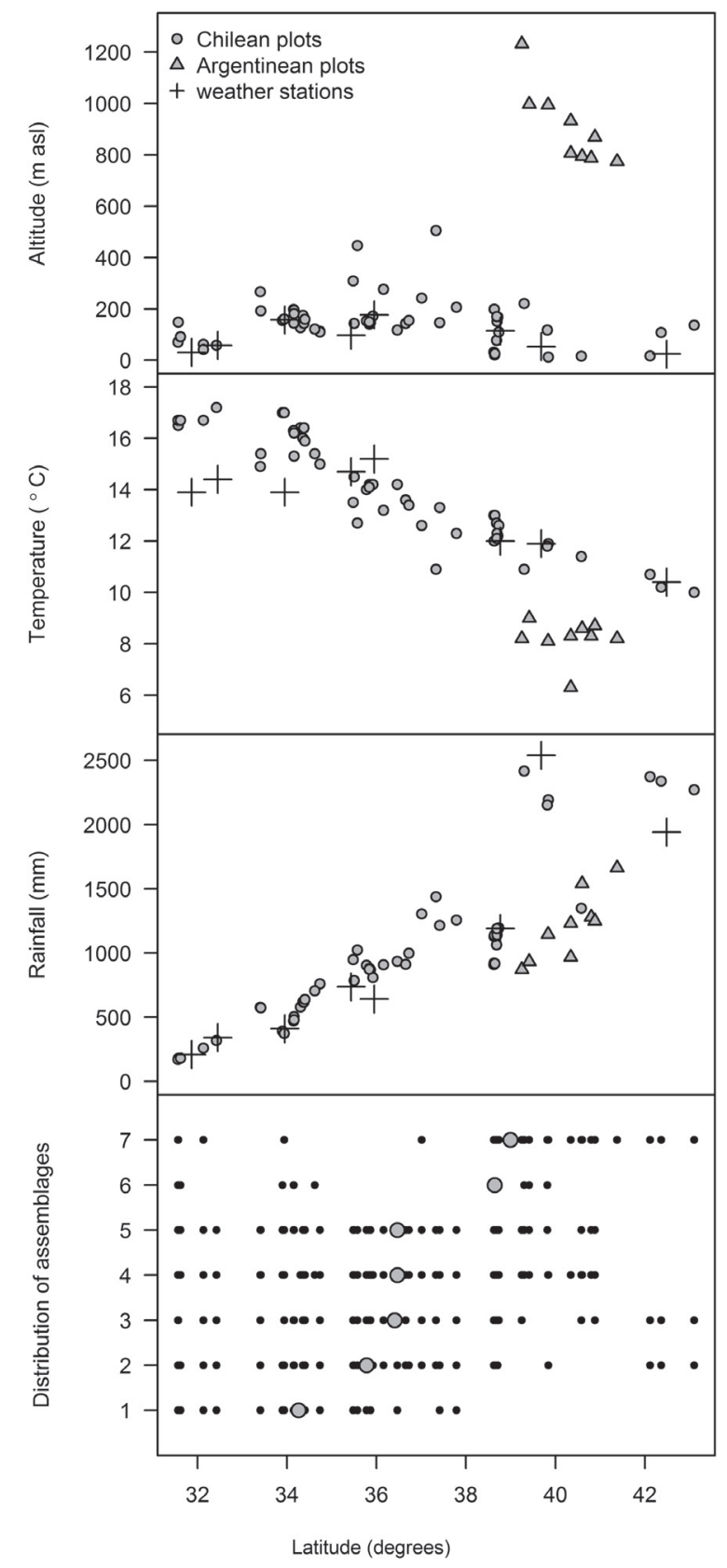

FIGURE 3. Geographic distribution of sampling localities and weather stations versus gradients of altitude, temperature and rainfall at the sampling localities according to the WorldClim database (Hijmans et al. 2005). Bottom plot shows the occurrence of species assemblages defined by hierarchical clustering (black dots), indicating their respective latitudinal medians (grey circles).

FIgURA 3. Distribución geográfica de las localidades muestreadas y de las estaciones meteorológicas comparadas con gradientes de altitud, temperatura y precipitación en los lugares de muestreo según el modelo WorldClim (Hijmans et al. 2005). El plot inferior muestra la presencia de ensambles definidos por la clasificación jerárquica (puntos negros), indicando sus respectivas medianas latitudinales (círculos grises).

\section{DISCUSSION}

SPECIES ASSEMBLAGES, SYNTAXONOMY AND MICRO-ENVIRONMENT Character species of vernal pool habitats are related to the Nanojuncetea australis (Deil 2005). Therefore this class is well represented in our dataset and is discriminated by the hierarchical clustering in the assemblages 3, 5 and 6 (Table III). Most of these clusters are dominated by annuals. On the other hand, assemblages 3, 6 and 7 are dominated by hemicryptophytes.

Within annuals, two groups can be distinguished according to flooding resistance: Centunculus minimus, Cicendia quadrangularis or Micropsis nana are dwarfish species, characterized by short life spans and a low tolerance to flooding duration (up to 30 days according to Keeley \& Zedler 1998), growing on pond edges. They belong to the "terrestrial damp species" sensu Casanova \& Brock (2000), which are able to germinate in watersaturated soils, finishing their life cycle in the terrestrial ecophase. Amphibious annuals like Hydrocotyle cryptocarpa, Navarretia involucrata or Ranunculus bonariensis var. trisepalus belong to the second group: These species are amphibious annuals, tolerating longer flooding periods. They respond to water level variations with a morphological plasticity ("amphibious fluctuation responders" sensu Casanova \& Brock 2000), mainly by changes in leaf morphology (Urban 1999). These species occur with preference in the bottom of seasonal pools (Bliss et al. 1998, Keeley \& Zedler 1998). Despite these two strategies allow the annuals to colonize different sites in an inundation gradient, the numerical classification mixed them in the assemblages, suggesting their cooccurrence due to a gradual transition from the aquatic to the terrestrial ecophase. Such intra-seasonal dynamic in the species composition was analysed by Rudner (2005) in the south of the Iberian Peninsula, where IsoëtoNanojuncetea communities are replaced in early summer by Helianthemetea guttati communities. A classification of seasonal wetland annuals according to the scheme proposed by Casanova \& Brock (2000) for Australia will require a detailed analysis of the phenology of the species in Chile.

Species grouped in assemblage 1 also belong to the dwarf annual growth form (nanism sensu Alvarez et al. 2012b). They characterize dry annual grassland (Deil et al. 2007) and are probably diagnostic species for the alliance Chaetanthero-Vulpion described by Oberdorfer (1960). Some of them are neophytes of European origin, linking their communities with the class Helianthemetea guttati of the Mediterranean area of the Western Palaearctic subkingdom. Among them we also find the native species Lepuropetalon spathulatum, one of the smallest dicotyledonous plants worldwide. The distribution of this species and its relation to vernal pools was studied in detail by Alvarez et al. 
(2012b). The syntaxonomic linkage between assemblage 1 and the vernal pool species suggest their assignment to Nanojuncetea australis.

Limoselletea australis species are poorly represented in our data set and not discriminated by the classification. For instance, Crassula peduncularis and Limosella australis, both considered as diagnostic for this class, join the Littorelletea species in assemblage 7. Though Limoselletea australis is considered by some authors as synonymous of Nanojuncetea australis (e.g. Galán de Mera 2005), its distribution along the Andean belt differs from the species of Nanojuncetea australis, clearly linked to the Mediterranean bioclimate. Additional samples of Limoselletea australis communities may be required to elucidate this question.

Species related to Littorelletea australis are mainly grouped in assemblage 7. These species colonize shorelines of oligotrophic lakes and streams with gravel or sand and are more frequent in the southern part of the study area (Oberdorfer 1960, Deil et al. 2011). Though some of these species are co-occurring with Nanojuncetea australis, there is a clear discrimination between both syntaxa (Deil et al. 2011), which is also reflected in our classification. Dynamic of this vegetation is strongly affected by a fluvio-glacial hydrological regime. The vegetation period is restricted by cool temperatures in winter and by submersion in summer (Deil 2005). Littorelletea species are able to grow permanently submerged as mentioned for example for Lilaeopsis macloviana by Affolter (1985). These species belong to the "long growing amphibious fluctuation tolerators" sensu Casanova \& Brock (2000).

\section{MACRO-CLIMATE AND PHYTOGEOGRAPHY OF SEASONAL WETLAND VEGETATION}

The occurrence of vernal pools specialists depends from local conditions like duration of inundation, small catchments triggered by rainfall, a subsurface hardpan with low water permeability and the chemical properties of soil and waterbody (Deil 2005, Deil et al. 2011). These conditions are on the one hand side strong environmental filters; on the other hand they can be quite similar over a broad macroclimatic gradient. These environmental conditions result in an azonal distribution of vernal pool vegetation, stated in this study for Chile, but also observed in Californian vernal pools (Zedler 1990). Since latitudinal distribution as well as rainfall and temperature are strongly correlated with PCA 1 (62.5\% of explained variance), the macro-climatic gradient contained in the dataset is near unidimensional. Dwarf annuals (assemblage 1), which probably depend more on the conditions of the surrounding environment, are more frequent in the dryer and warmer conditions in Northern Chile. On the other hand, Littorelletea australis species (assemblage 7) are more frequent in the humid and colder climate in the South. Most of the species assemblages take a high position in PCA 2, indicating their preferences to a strong seasonality of the temperature (Table IV, Fig. 4). Only the assemblages 6 and 7 tend to lower PCA 2 scores. The PCA 3 scores have a high negative correlation with isothermality $(10.7 \%$ of explained variance), which is defined as the mean diurnal range divided by the annual range. They show a less clear trend in the distribution of assemblages (Fig. 4).

The occurrence of vernal pools partially resembles the distribution of Centipeda elatinoides, Soliva spp. (MoreiraMuñoz \& Muñoz-Schick 2007), Hydrocotyle cryptocarpa (Alvarez et al. 2008) and Lepuropetalon spathulatum (Alvarez et al. 2012b). These diagnostic species are only missing in the plots from the island of Chiloé and from Argentina. Lasthenia kunthii is widespread southwards (Moreira-Muñoz \& Muñoz-Schick 2007) and occurs also in ephemeral wetlands in Patagonia (San Martín et al. 2013).

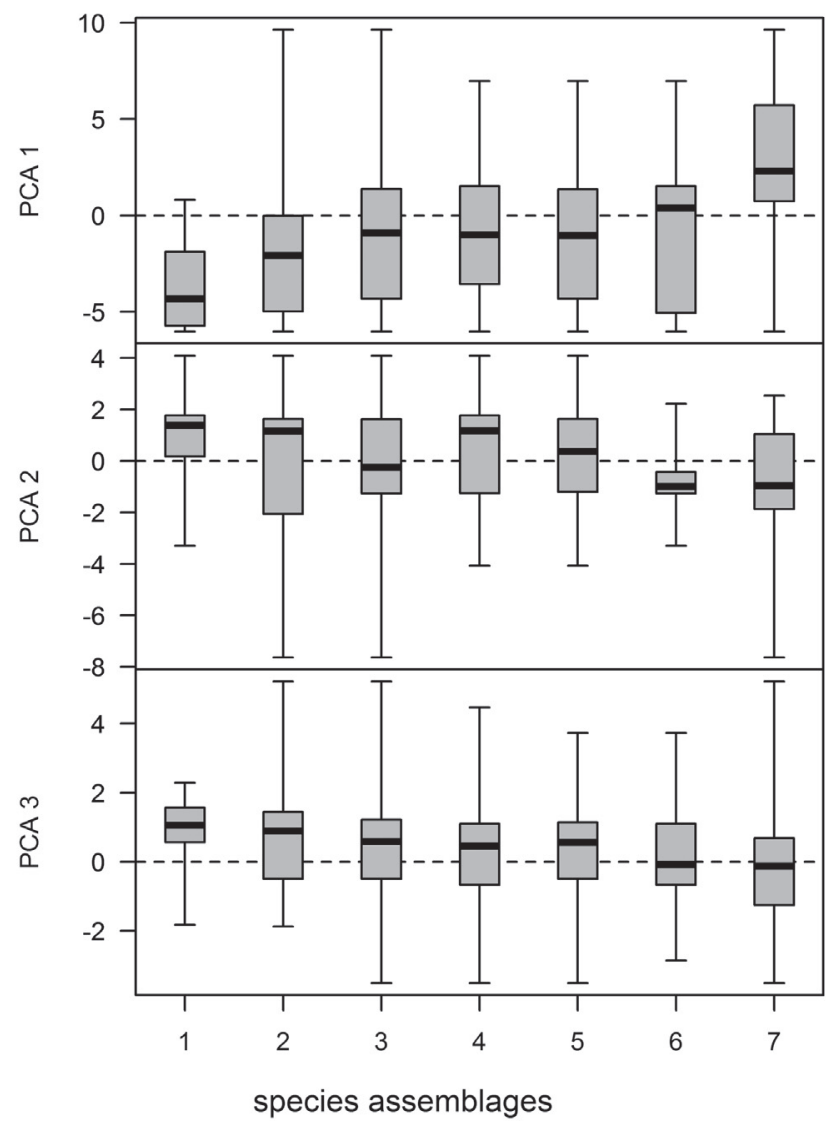

Figure 4. Boxplots showing the distribution of species assemblages (x axis) defined by hierarchical clustering in the first three PCA scores.

Figura 4. Boxplots mostrando la distribución de ensambles de especies (eje de abscisas) definidos por la clasificación jerárquica en las tres primeras dimensiones del PCA. 
The existence of vernal pools in the study area is linked to different ecoregions. In the semi-arid climatic belt in the north $\left(31^{\circ}\right.$ to $\left.34^{\circ} \mathrm{S}\right)$, vernal pools are scattered over the littoral plains. Southwards from the Mediterranean into the temperate bioclimate $\left(34^{\circ}\right.$ to $\left.44^{\circ} \mathrm{S}\right)$ they occur preferentially in the Central Valley and along the eastern slopes of the Coastal Mountain Range. Littorelletea species, which are better represented in assemblage 7, grow preferentially on the fringes of the big lakes in the Chilean Lake District ( $39^{\circ}$ to $42^{\circ} \mathrm{S}$ ) and on shorelines of lakes and streams in the Andes and Patagonian lowlands, in Chile as well as in Argentina (Deil et al. 2011). These landscapes were shaped by glaciations, the substrates are stony and sandy and the waters are oligo- to mesotrophic (Oberdorfer 1960).

TABLE IV. Loadings of the environmental factors in the three first PCA axes and summarizing statistics of the principal component analysis (PCA). Variables are separated in four groups: 1) strong negative correlation with the first axis, 2) strong positive correlation with the first axis, 3) strong positive correlation with the second axis, and 4) strong negative correlation with the third axis.

TABLA IV. Vectores de los factores ambientales para las primeras tres dimensiones de PCA y estadísticas del análisis de componentes principales (PCA). Las variables están separadas en cuatro grupos: 1) correlacionadas negativamente con la primera dimensión, 2) correlacionadas positivamente con la primera dimensión, 3) correlacionadas positivamente con la segunda dimensión, y 4) correlacionadas negativamente con la tercera dimensión.

\begin{tabular}{|c|c|c|c|c|}
\hline Code & FACTOR & PCA 1 & PCA 2 & PCA 3 \\
\hline bio_9 & Mean temperature of the driest quarter & -0.265 & 0.004 & 0.226 \\
\hline bio_10 & Mean temperature of the warmest quarter & -0.265 & 0.010 & 0.234 \\
\hline bio_1 & Annual mean temperature & -0.262 & -0.113 & 0.202 \\
\hline bio_5 & Max temperature of the warmest month & -0.244 & 0.164 & 0.207 \\
\hline bio_15 & Precipitation seasonality (coefficient of variation) & -0.241 & 0.132 & 0.125 \\
\hline bio_8 & Mean temperature of the wettest quarter & -0.243 & -0.207 & 0.185 \\
\hline bio_11 & Mean temperature of the coldest quarter & -0.242 & -0.219 & 0.171 \\
\hline bio_6 & Min temperature of the coldest month & -0.226 & -0.265 & 0.183 \\
\hline lat & Latitude & 0.265 & -0.013 & -0.045 \\
\hline bio_17 & Precipitation of the driest quarter & 0.267 & -0.126 & 0.112 \\
\hline bio_18 & Precipitation of the warmest quarter & 0.265 & -0.134 & 0.116 \\
\hline bio_14 & Precipitation of the driest month & 0.261 & -0.152 & 0.121 \\
\hline bio_12 & Annual precipitation & 0.255 & -0.020 & 0.260 \\
\hline bio_19 & Precipitation of the coldest quarter & 0.230 & 0.059 & 0.333 \\
\hline bio_16 & Precipitation of the wettest quarter & 0.227 & 0.074 & 0.343 \\
\hline bio_13 & Precipitation of the wettest month & 0.222 & 0.128 & 0.348 \\
\hline bio_7 & Temperature annual range (bio_5 - bio_6) & -0.047 & 0.497 & 0.049 \\
\hline bio_4 & Temperature seasonality (standard deviation) & -0.035 & 0.486 & 0.110 \\
\hline bio_2 & Mean diurnal temperature range & -0.042 & 0.454 & -0.141 \\
\hline \multirow[t]{5}{*}{ bio_3 } & Isothermality (bio_2/bio_7) & -0.012 & -0.095 & -0.451 \\
\hline & Summarizing PCA statistics & & & \\
\hline & Standard deviation & 3.535 & 1.950 & 1.463 \\
\hline & Proportion of Variance & 0.625 & 0.190 & 0.107 \\
\hline & Cumulative Proportion & 0.625 & 0.815 & 0.922 \\
\hline
\end{tabular}


Though neophytes are very frequent in Chilean vernal pools, the high dominance of native species in most of the co-occurrence groups suggests low risks of extinction by out- competition. Nevertheless, more detailed synecological studies are required for a proper assessment.

The species assemblages defined here can be used as starting groups for supervised classification strategies (e.g. Cocktail method; Bruelheide 2000) as well as to search for indicator species of seasonal wetland types. An enlargement of the database and further collection of field data will improve the knowledge about the vegetation ecology of vernal pools and will allow a better classification of the communities in Chile and elsewhere in South America.

\section{ACKNOWLEDGEMENTS}

Financial support for data collection during a field survey in 2009 by the Faculty of Biology, University of Freiburg is greatly acknowledged. Also crucial for this work were later field surveys in Chile supported by the Otti Wilmanns Foundation and the A.F.W. Schimper Foundation, both placed in Germany. The authors also thank to Prof. Dr. Michael Rudner (University Weihenstephan-Triesdorf) for his valuable comments to a first version of this manuscript.

\section{BIBLIOGRAPHY}

AfFolter, J.M. 1985. A monograph of the genus Lilaeopsis (Umbelliferae). American Society of Plant Taxonomists, Michigan. Systematic Botany Monographs 6: 1-140.

Alvarez, M. 2008. Diasporenbank und Ökologie der Vegetation temporärer Gewässer im Cholchol-Gebiet (9. Region, Chile). J. Cramer, Berlin. Dissertationes Botanicae 407: $1-87$.

Alvarez, M., C. Ramírez \& U. Deil. 2008. Ecología y distribución de Hydrocotyle cryptocarpa Speg. en Sudamérica. Gayana Botánica 65: 139-144.

Alvarez, M., B.M. Möseler, C. San Martín, C. Ramírez \& J. Amigo. 2012a. CL-Dataveg - a database of Chilean grassland vegetation. Biodiversity and Ecology 4: 443.

Alvarez, M., J. San Martín \& U. Deil. 2012b. Nanism and ephemerism as reasons for a hidden abundance in vernal pool plants: the example of Lepuropetalon spathulatum in Chile. Feddes Repertorium 123: 55-66.

Amigo, J. \& C. Ramírez. 1998. A bioclimatic classification of Chile: woodland communities in the temperate zone. Plant Ecology 136: 9-26.

Arroyo, M.T.K., C. Marticorena \& M. Muñoz. 1990. A checklist of the native annual flora of continental Chile. Gayana Botánica 47: 119-135.

Backhaus, K., B. Erichson, W. Plinke \& R. Weiber. 2006. Multivariate Analysemethoden. Springer, Berlin. 830 pp.

Bannister, J.R., O.J. Vidal, E. Teneb \& V. Sandoval. 2012. Latitudinal patterns and regionalization of plant diversity along a 4270-km gradient in continental Chile. Austral
Ecology 37: 500-509.

Barbour, M.G., A.I. Solomeshch, C.W. Witham, R.F. Holland, R.L. MacDonald, S.S. Cilliers, J.A. Molina, J.J. Buck \& J.M. Hillman. 2003. Vernal pool vegetation of California: variation within pools. Madroño 50: 129-146.

Bliss, S.A., P.H. Zedler, J.E. Keeley \& M.T.K. Arroyo. 1998. A floristic survey of the temporary wetlands in the Mediterranean-climate region of Chile. In: A.J. McComb \& J.A. Davis (eds.), Wetlands for the future, pp. 219-228. Gleneagles, Adelaide.

Bruelheide, H. 2000. A new measure of fidelity and its application to defining species groups. Journal of Vegetation Science 11: $167-178$.

Casanova, M.T. \& M.A. Brock. 2000. How do depth, duration and frequency of flooding influence the establishment of wetland plant communities? Plant Ecology 147: 237-250.

DeIL, U. 2005. A review on habitats, plant traits and vegetation of ephemeral wetlands - a global perspective. Phytocoenologia 35: 533-705.

Deil, U. \& M. Alvarez. 2012. Database of ephemeral wetland vegetation in extra- and oro-tropical South America. Biodiversity and Ecology 4: 441.

Deil, U., M. Alvarez \& I. Paulini. 2007. Native and non-native species in annual grassland vegetation in Mediterranean Chile. Phytocoenologia 37: 769-784.

Deil, U., M. Alvarez, E.-M. Bauer \& C. Ramírez. 2011. The vegetation of seasonal wetlands in extratropical and orotropical South America. Phytocoenologia 41: 1-34.

Dengler, J., F. Jansen, F. Glöckler, R.K. Peet, M. de Cáceres, M. Chytrý, J. Ewald, J. Oldeland, G. López-GonzÁlez, M. Finckh, L. Mucina, J.S. Rodwell, J.H.J. Schaminée \& N. SPEnCER. 2011. The Global Index of Vegetation-Plot Databases (GIVD): a new resource for vegetation science. Journal of Vegetation Science 22: 582-597.

EsKuche, U.G. 2005. Las comunidades vegetales litorales de los lagos patagónicos y de los canales magallánicos. Folia Botanica et Geobotanica Correntesiana 18: 1-31.

Galán de Mera, A. 2005. Clasificación fitosociológica de la vegetación de la región del Caribe y América del Sur. Arnaldoa 12: 86-111.

Gerhardt, F. \& S.K. Collinge. 2003. Exotic plant invasions of vernal pools in the Central Valley of California, USA. Journal of Biogeography 30: 1043-1052.

Hennekens, S.M. \& J.H.J. Schaminée. 2001. TURBOVEG, a comprehensive data base management system for vegetation data. Journal of Vegetation Science 12: 589591.

Hijmans, R.J., S.E. Cameron, J.L. Parra, P.G. Jones \& A. Jarvis. 2005. Very high resolution interpolated climate surfaces for global land areas. International Journal of Climatology 25: 1965-1978.

Jansen, F. \& J. Dengler. 2010. Plant names in vegetation databases - a neglected source of bias. Journal of Vegetation Science 21: 1179-1186.

Keeley, J.E. \& P.H. ZedLer. 1998. Characterization and global distribution of vernal pools. In: C.W. Witham, E.T. Bauder, D. Belk, W.R. Ferren \& R. Ornduff (eds.), Ecology, conservation, and management of vernal pool ecosystems - Proceedings from a 1996 conference, pp. 1-14. California Native Plant Society, Sacramento. 
Luebert, F. \& P. Pliscoff. 2006. Sinopsis bioclimática y vegetacional de Chile. Editorial Universitaria, Santiago de Chile. 316 pp.

Mielke, P.W., K.J. Berry, P.J. Brockwell \& J.S. Williams. 1981. A class of nonparametric tests based on multiresponse permutation procedures. Biometrika 68: 720-724.

Moreira-Muñoz, A. 2011. Plant Geography of Chile. Springer, Dordrecht. Plant and Vegetation 5: 1-320.

Moreira-Muñoz, A. \& M. MuÑoz-SCHICK. 2007. Classification, diversity, and distribution of Chilean Asteraceae: implications for biogeography and conservation. Diversity and Distributions 13: 818-828.

Murtagh, F. \& P. Legendre. 2014. Ward's hierarchical agglomerative clustering method: which algorithm implement Ward's criterion? Journal of Classification 31: 274-295.

Oberdorfer, E. 1960. Pflanzensoziologische Studien in Chile. J. Cramer, Weinheim. Flora et Vegetatio Mundi 2: 1-208.

Potт, R. \& D. Remy. 2000. Gewässer des Binnenlandes. Eugen Ulmer, Stuttgart. 255 pp.

Ramírez, C., C. San Martín, D. Contreras \& J. San Martín. 1994. Estudio fitosociológico de la vegetación pratense del valle del río Chol-Chol (Cautín, Chile). Agro Sur 22: 41-56.

Ramírez, C., C. San Martín \& M.L. Keim. 1996. La vegetación espontánea del antiguo basural de Ovejería (Osorno, Chile). Medio Ambiente 13: 42-57.

Rudner, M. 2005. Seasonal and interannual dynamics in dwarf rush vegetation in the Southwestern Iberian Peninsula. Phytocoenologia 35: 403-420.
San Martín, C., C. Ramírez \& P. Ojeda. 1998. La vegetación de lagunas primaverales en las cercanías de Temuco (Cautín, Chile). Acta Botanica Malacitana 23: 99-120.

San Martín, C., Y. Pérez, M. Alvarez, C. Salazar \& C. Ramírez. 2013. Diversidad vegetal de lagunas temporales en la estepa patagónica chilena noroccidental. Anales Instituto Patagonia 41: 111-116.

Urban, K.E. 1999. Plastizität bei Pflanzenarten der Heideweiher. Mitteilungen des Badischen Landesvereins für Naturkunde und Naturschutz 17: 309-321.

VAN DER MAAREL, E. 1979. Transformation of cover-abundance values in phytosociology and its effects on community similarity. Vegetatio 39: 97-114.

Van Sickle, J. \& R.M. Hughes. 2000. Classification strengths of ecoregions, catchments, and geographic clusters for aquatic vertebrates in Oregon. Journal of the North American Benthological Society 19: 370-384.

Wilson, J.B., T.R. Partridge \& M.T. Sykes. 1990. The use of the Cole/Hurlbert $\mathrm{C}_{8}$ association coefficient in inverse ecological classification. Journal of Vegetation Science 1: 367-374.

ZEDLER, P.H. 1990. Life histories of vernal pool vascular plants. In: D.H. Ikeda \& R.A. Schlising (eds.), Vernal pool plants - their habitat and biology, pp. 123-146. Herbarium CSU Chico, California.

Zuloaga, F., O. Morrone \& M. Belgrano (eds.). 2008. Catálogo de las plantas vasculares del Cono Sur (Argentina, Sur de Brasil, Chile, Paraguay y Uruguay). Monograph in Systematic botany from the Missouri Botanical Garden, Vol. 107. Missouri, U.S.A. 3348 pp.

ApPEndix A. List of species used for the classification and respective attributes (groups defined a priori, life forms, status and assigned assemblage). Nomenclature of species according Zuloaga et al. (2008). Groups defined a priori (according to Deil et al. 2011 and Deil et al. 2007) are coded as NAA (Nanojuncetea australis), LMO (Limoselletea australis), LTT (Littorelletea australis), ANN (dwarf annuals), and comp. (companion species). Life forms are coded as T (therophytes), $\mathrm{Cr}$ (cryptophytes), $\mathrm{H}$ (hemicryptophytes), and Ch (chamaephytes). Species status is either native $(\mathrm{N})$ or introduced $(\mathrm{I})$.

APÉNDICE A. Lista de especies usadas para la clasificación y sus respectivos atributos (grupos definidos a priori, formas de vida, estatus y ensamble asignado). Nomenclatura de especies según Zuloaga et al. (2008). Los grupos definidos a priori (según Deil et al. 2011 y Deil et al. 2007) son codificados como NAA (Nanojuncetea australis), LMO (Limoselletea australis), LTT (Littorelletea australis), ANN (nanoterófitas), y comp. (especies acompañantes). Las formas de vida son abreviadas como T (terófitas), Cr (criptófitas), H (hemicriptófitas), y Ch (caméfitas). Origen de especies es nativo (N) o introducido (I).

\begin{tabular}{|c|c|c|c|c|c|}
\hline Code & SCIENTIFIC NAME & GROUP & LIFE FORM & Status & Assemb. \\
\hline AGROCAP & Agrostis capillaris & comp. & $\mathrm{H}$ & I & 3 \\
\hline AGROMAG & Agrostis magellanica & comp. & $\mathrm{H}$ & $\mathrm{N}$ & 7 \\
\hline AIRACAR & Aira caryophyllea & ANN & $\mathrm{T}$ & I & 2 \\
\hline ANAGALT & Anagallis alternifolia & LTT & $\mathrm{H}$ & $\mathrm{N}$ & 7 \\
\hline ANTHCOT & Anthemis cotula & comp. & $\mathrm{T}$ & I & 1 \\
\hline APHAARV & Aphanes arvensis & comp. & $\mathrm{T}$ & I & 2 \\
\hline ARENSER & Arenaria serpens & comp. & $\mathrm{H}$ & $\mathrm{N}$ & 7 \\
\hline AZORTRI & Azorella trifoliolata & LTT & $\mathrm{H}$ & $\mathrm{N}$ & 7 \\
\hline BLENCHI & Blennosperma chilense & NAA & $\mathrm{T}$ & $\mathrm{N}$ & 2 \\
\hline BRIZMIN & Briza minor & ANN & $\mathrm{T}$ & I & 3 \\
\hline BROMTRI & Bromidium trisetoides & NAA & $\mathrm{T}$ & $\mathrm{N}$ & 2 \\
\hline CALL.SP & Callitriche sp. & comp. & $\mathrm{T}$ & $\mathrm{N}$ & 4 \\
\hline
\end{tabular}


Appendix A. Continuation.

ApÉnDICE A. Continuación.

\begin{tabular}{|c|c|c|c|c|c|}
\hline CODE & SCIENTIFIC NAME & GROUP & LIFE FORM & Status & ASSEMB. \\
\hline CALOBRI & Calotheca brizoides & NAA & $\mathrm{H}$ & $\mathrm{N}$ & 3 \\
\hline CARDCHI & Cardamine chilensis & comp. & $\mathrm{T}$ & $\mathrm{N}$ & 4 \\
\hline CARDVAL & Cardamine valdiviana & NAA & $\mathrm{Cr}$ & $\mathrm{N}$ & 5 \\
\hline CAREDEC & Carex decidua & LTT & $\mathrm{H}$ & $\mathrm{N}$ & 7 \\
\hline CAREFUS & Carex fuscula & comp. & $\mathrm{H}$ & $\mathrm{N}$ & 5 \\
\hline CASTLAC & Castilleja laciniata & comp. & $\mathrm{T}$ & $\mathrm{N}$ & 2 \\
\hline CENTELA & Centipeda elatinoides & NAA & $\mathrm{H}$ & $\mathrm{N}$ & 6 \\
\hline CENTMIN & Centunculus minimus & NAA & $\mathrm{T}$ & I & 4 \\
\hline CERAGLO & Cerastium glomeratum & ANN & $\mathrm{T}$ & $\mathrm{I}$ & 1 \\
\hline CICEQUA & Cicendia quadrangularis & NAA & $\mathrm{T}$ & $\mathrm{N}$ & 5 \\
\hline CLARTEN & Clarkia tenella & comp. & $\mathrm{T}$ & $\mathrm{N}$ & 1 \\
\hline CONACAM & Conanthera campanulata & comp. & $\mathrm{Cr}$ & $\mathrm{N}$ & 1 \\
\hline CRASCLO & Crassula closiana & $\mathrm{ANN}$ & $\mathrm{T}$ & $\mathrm{N}$ & 1 \\
\hline CRASPAL & Crassula paludosa & comp. & $\mathrm{T}$ & $\mathrm{N}$ & 4 \\
\hline CRASPED & Crassula peduncularis & LMO & $\mathrm{T}$ & $\mathrm{N}$ & 7 \\
\hline CUSC.SP & Cuscuta sp. & comp. & $\mathrm{T}$ & $\mathrm{N}$ & 4 \\
\hline CYNOECH & Cynosurus echinatus & comp. & $\mathrm{T}$ & I & 3 \\
\hline CYPEREF & Cyperus reflexus & NAA & $\mathrm{H}$ & $\mathrm{N}$ & 6 \\
\hline DESCDAN & Deschampsia danthonioides & NAA & $\mathrm{T}$ & $\mathrm{N}$ & 2 \\
\hline DICHSER & Dichondra sericea & NAA & $\mathrm{H}$ & $\mathrm{N}$ & 5 \\
\hline DOWNPUS & Downingia pusilla & LTT & $\mathrm{T}$ & $\mathrm{N}$ & 4 \\
\hline ELEOMAC & Eleocharis macrostachya & comp. & $\mathrm{Cr}$ & $\mathrm{N}$ & 4 \\
\hline ELEOPAC & Eleocharis pachycarpa & LTT & $\mathrm{Cr}$ & $\mathrm{N}$ & 7 \\
\hline EPILSUB & Epilobium subdentatum & comp. & $\mathrm{T}$ & $\mathrm{N}$ & 3 \\
\hline EQUIBOG & Equisetum bogotense & LTT & $\mathrm{Cr}$ & $\mathrm{N}$ & 7 \\
\hline ERODCIC & Erodium cicutarium & comp. & $\mathrm{T}$ & I & 1 \\
\hline ERODMAL & Erodium malacoides & comp. & $\mathrm{T}$ & I & 2 \\
\hline ERYNPSE & Eryngium pseudojunceum & NAA & $\mathrm{H}$ & $\mathrm{N}$ & 6 \\
\hline ERYN.SP & Eryngium sp. & comp. & $\mathrm{H}$ & $\mathrm{N}$ & 4 \\
\hline EUPHMEI & Euphrasia meiantha & comp. & $\mathrm{T}$ & $\mathrm{N}$ & 2 \\
\hline GAMOSPI & Gamochaeta spiciformis & NAA & $\mathrm{H}$ & $\mathrm{N}$ & 3 \\
\hline GLINRAD & Glinus radiatus & comp. & $\mathrm{T}$ & $\mathrm{N}$ & 7 \\
\hline GRATPER & Gratiola peruviana & NAA & $\mathrm{H}$ & $\mathrm{N}$ & 6 \\
\hline HERBLAH & Herbertia lahue & comp. & $\mathrm{Cr}$ & $\mathrm{N}$ & 5 \\
\hline HORDMAR & Hordeum marinum & comp. & $\mathrm{T}$ & I & 5 \\
\hline HYDRCHA & Hydrocotyle chamaemorus & LTT & $\mathrm{H}$ & $\mathrm{N}$ & 7 \\
\hline HYDRCRY & Hydrocotyle cryptocarpa & NAA & $\mathrm{T}$ & $\mathrm{N}$ & 4 \\
\hline HYPOGLA & Hypochaeris glabra & ANN & $\mathrm{T}$ & I & 2 \\
\hline HYPORAD & Hypochaeris radicata & comp. & $\mathrm{H}$ & I & 3 \\
\hline HYPO.SP & Hypochaeris sp. & comp. & $\mathrm{H}$ & $\mathrm{N}$ & 5 \\
\hline ISOESAV & Isoëtes chubutiana & LTT & $\mathrm{Cr}$ & $\mathrm{N}$ & 4 \\
\hline ISOLCER & Isolepis cernua & comp. & $\mathrm{T}$ & $\mathrm{N}$ & 4 \\
\hline
\end{tabular}


Appendix A. Continuation.

ApÉndice A. Continuación.

\begin{tabular}{|c|c|c|c|c|c|}
\hline CodE & SCIENTIFIC NAME & GROUP & LIFE FORM & Status & ASSEMB \\
\hline ISOLINU & Isolepis inundata & LTT & $\mathrm{Cr}$ & I & 7 \\
\hline JUNCB.A & Juncus balticus subsp. andicola & LTT & $\mathrm{H}$ & $\mathrm{N}$ & 7 \\
\hline JUNCBUF & Juncus bufonius & NAA & $\mathrm{T}$ & I & 2 \\
\hline JUNCCAP & Juncus capitatus & NAA & $\mathrm{T}$ & I & 2 \\
\hline JUNCIMB & Juncus imbricatus & NAA & $\mathrm{H}$ & $\mathrm{N}$ & 3 \\
\hline JUNCPAL & Juncus pallescens & LMO & $\mathrm{H}$ & $\mathrm{N}$ & 5 \\
\hline JUNCPLA & Juncus planifolius & NAA & $\mathrm{H}$ & $\mathrm{N}$ & 3 \\
\hline JUNCPRO & Juncus procerus & NAA & $\mathrm{H}$ & $\mathrm{N}$ & 6 \\
\hline JUNC.SP & Juncus sp. & comp. & $\mathrm{H}$ & $\mathrm{N}$ & 4 \\
\hline JUNCSTI & Juncus stipulatus & LTT & $\mathrm{H}$ & $\mathrm{N}$ & 7 \\
\hline LASTKUN & Lasthenia kunthii & NAA & $\mathrm{T}$ & $\mathrm{N}$ & 4 \\
\hline LEONTAR & Leontodon taraxacoides & NAA & $\mathrm{T}$ & I & 5 \\
\hline LEPTMIC & Leptophyllochloa micrathera & LTT & $\mathrm{H}$ & $\mathrm{N}$ & 7 \\
\hline LEPUSPA & Lepuropetalon spathulatum & comp. & $\mathrm{T}$ & $\mathrm{N}$ & 2 \\
\hline LILASCI & Lilaea scilloides & comp. & $\mathrm{T}$ & $\mathrm{N}$ & 4 \\
\hline LIMOAUS & Limosella australis & LMO & $\mathrm{T}$ & $\mathrm{N}$ & 7 \\
\hline LINUCHA & Linum chamissonis & comp. & $\mathrm{Ch}$ & $\mathrm{N}$ & 5 \\
\hline LITTAUS & Littorella australis & LTT & $\mathrm{Cr}$ & $\mathrm{N}$ & 7 \\
\hline LOLITEM & Lolium temulentum & comp. & $\mathrm{T}$ & I & 5 \\
\hline LOTUSUB & Lotus subpinnatus & NAA & $\mathrm{T}$ & $\mathrm{N}$ & 5 \\
\hline LYTHHYS & Lythrum hyssopifolia & NAA & $\mathrm{T}$ & I & 4 \\
\hline LYTHPOR & Lythrum portula & NAA & $\mathrm{T}$ & I & 7 \\
\hline MEDIPOL & Medicago polymorpha & ANN & $\mathrm{T}$ & I & 1 \\
\hline MENTPUL & Mentha pulegium & NAA & $\mathrm{H}$ & I & 5 \\
\hline MICRNAN & Micropsis nana & NAA & $\mathrm{T}$ & $\mathrm{N}$ & 3 \\
\hline MICRPYG & Microseris pygmaea & ANN & $\mathrm{T}$ & $\mathrm{N}$ & 1 \\
\hline MONTFON & Montia fontana & comp. & $\mathrm{T}$ & $\mathrm{N}$ & 2 \\
\hline NASSPOE & Nassella poeppigiana & NAA & $\mathrm{H}$ & $\mathrm{N}$ & 3 \\
\hline NAVAINV & Navarretia involucrata & NAA & $\mathrm{T}$ & $\mathrm{N}$ & 5 \\
\hline NOTHGRA & Nothoscordum gramineum & NAA & $\mathrm{Cr}$ & $\mathrm{N}$ & 4 \\
\hline OXALMIC & Oxalis micrantha & ANN & $\mathrm{T}$ & $\mathrm{N}$ & 1 \\
\hline OXAL.SP & Oxalis sp. & comp. & $\mathrm{Cr}$ & $\mathrm{N}$ & 4 \\
\hline OZIRBIF & Oziroë biflora & ANN & $\mathrm{Cr}$ & $\mathrm{N}$ & 1 \\
\hline PASPDAS & Paspalum dasypleurum & NAA & $\mathrm{H}$ & $\mathrm{N}$ & 3 \\
\hline PHALAME & Phalaris amethystina & comp. & $\mathrm{T}$ & $\mathrm{N}$ & 5 \\
\hline PHYLNOD & Phyla nodiflora & NAA & $\mathrm{H}$ & $\mathrm{N}$ & 6 \\
\hline PILUAME & Pilularia americana & comp. & $\mathrm{Cr}$ & $\mathrm{N}$ & 4 \\
\hline PIPTMON & Piptochaetium montevidense & NAA & $\mathrm{H}$ & $\mathrm{N}$ & 3 \\
\hline PLAGCMB & Plagiobothrys corymbosus & LTT & $\mathrm{T}$ & $\mathrm{N}$ & 4 \\
\hline PLAGPRA & Plagiobothrys pratensis & NAA & $\mathrm{T}$ & $\mathrm{N}$ & 5 \\
\hline PLAGPRO & Plagiobothrys procumbens & ANN & $\mathrm{T}$ & $\mathrm{N}$ & 1 \\
\hline PLANFIR & Plantago firma & comp. & $\mathrm{T}$ & $\mathrm{N}$ & 2 \\
\hline
\end{tabular}


Appendix A. Continuation.

APÉNDICE A. Continuación.

\begin{tabular}{|c|c|c|c|c|c|}
\hline Code & SCIENTIFIC NAME & Group & LIFE FORM & Status & AssEmB. \\
\hline PLANLAN & Plantago lanceolata & comp. & $\mathrm{H}$ & I & 5 \\
\hline POLYHDS & Polygonum hydropiperoides & NAA & $\mathrm{H}$ & I & 6 \\
\hline POLYAUS & Polypogon australis & comp. & $\mathrm{H}$ & $\mathrm{N}$ & 7 \\
\hline GNAPCYM & Pseudognaphalium cymathoides & NAA & $\mathrm{T}$ & $\mathrm{N}$ & 6 \\
\hline PSILBRE & Psilocarphus brevissimus & comp. & $\mathrm{T}$ & $\mathrm{N}$ & 4 \\
\hline RANUB.T & Ranunculus bonariensis var. trisepalus & comp. & $\mathrm{T}$ & $\mathrm{N}$ & 4 \\
\hline RANUHYD & Ranunculus hydrophilus & LTT & $\mathrm{T}$ & $\mathrm{N}$ & 7 \\
\hline RUMEACE & Rumex acetosella & ANN & $\mathrm{H}$ & I & 3 \\
\hline RUMECRI & Rumex crispus & comp. & $\mathrm{H}$ & I & 7 \\
\hline SENEZOS & Senecio zosterifolius & LTT & $\mathrm{H}$ & $\mathrm{N}$ & 7 \\
\hline SISYGRA & Sisyrinchium graminifolium & NAA & $\mathrm{Cr}$ & $\mathrm{N}$ & 2 \\
\hline SOLISES & Soliva sessilis & ANN & $\mathrm{T}$ & $\mathrm{N}$ & 2 \\
\hline SPERRUB & Spergula rubra & comp. & $\mathrm{H}$ & I & 6 \\
\hline SYMPVAH & Symphyotrichum vahlii & comp. & $\mathrm{H}$ & $\mathrm{N}$ & 7 \\
\hline TRIFDUB & Trifolium dubium & comp. & $\mathrm{T}$ & I & 2 \\
\hline TRIFSUB & Trifolium subterraneum & comp. & $\mathrm{T}$ & I & 2 \\
\hline VEROP.X & Veronica peregrina subsp. xalapensis & comp. & $\mathrm{T}$ & I & 5 \\
\hline VULPBRO & Vulpia bromoides & ANN & $\mathrm{T}$ & I & 5 \\
\hline
\end{tabular}

Recibido: 14.01 .15

Aceptado: 06.07.15 